\title{
El inventario de arquitectura del siglo XX en España presenta los primeros resultados
}

El pasado 27 de junio tuvo lugar en la sede del IAPH la presentación del Inventario de la Arquitectura del siglo XX en España, trabajo realizado en el marco del proyecto ARCHSXX para la documentación y difusión de la arquitectura del siglo XX en las regiones del Suroeste europeo. Dicho proyecto ha contado con la participación activa del IAPH, a través de la transferencia de los resultados del Registro Andaluz de Arquitectura Contemporánea (RAAC), con el que comparte los objetivos de documentar, proteger y difundir los valores patrimoniales de la arquitectura contemporánea (ver sección Bienes, paisajes e itinerarios del presente número).

\section{El patrimonio arquitectónico contemporáneo se ve frecuentemente comprometido por la velocidad actual de los cambios urbanos y territoriales}

\begin{abstract}
En el marco de la presentación, las intervenciones del director de la Fundación Docomomo lbérico, Lluís Hortet Previ, y del director del IAPH, Román Fernández-Baca, coincidieron en la necesidad de promover iniciativas de salvaguarda de un patrimonio arquitectónico contemporáneo de enorme valor y cuya conservación se ve frecuentemente comprometida por la velocidad con que los cambios urbanos y territoriales se suceden en la actualidad.
\end{abstract}

La descripción del proyecto y los trabajos realizados corrió a cargo de su coordinador general, Carlos García Vázquez, quien ofreció una perspectiva de la labor de documentación llevada a cabo en España, las regiones del sur de Francia y Gibraltar, quedando de manifiesto su notable envergadura así como la ambición de los objetivos que se plantean una vez culminada la fase de documentación. A continuación, los coordinadores y representantes de las cinco zonas en las que se ha estructurado el trabajo mostraron aspectos generales y particulares del proyecto: Fernando Agrasar, coordinador de la zona Norte-Cantábrico, diseccionó valiosos ejemplos de la producción arquitectónica nuevamente documentados en esa región con motivo de esta iniciativa; mientras que la presentación de Iñaki Bergera, coordinador de la zona NorteValle del Ebro, apuntó a casos concretos de arquitecturas amenazadas, arquitecturas trans- formadas y arquitecturas desconocidas, a las que con ocasión del Inventario se les ha ofrecido una plataforma desde la que reivindicar su indiscutible calidad.

Las intervenciones de Miguel Lasso de la Vega, coordinador de la zona Centro, Paolo Sustersic, como representante del equipo de trabajo de la zona Este, y de Plácido González, coordinador del Registro Andaluz de Arquitectura Contemporánea, ofrecieron aproximaciones diversas, centradas en las metodologías de trabajo seguidas en sus correspondientes regiones, e ilustradas a través de una selección de imágenes de inmuebles relevantes y casos de estudio significativos, que sirvieron de instantáneas de la enorme riqueza del paisaje construido en estas regiones durante el pasado siglo.

La notable repercusión de la presentación del Inventario en los medios de comunicación, tanto a nivel general como para la prensa especializada, supone un gran impulso a las tareas de sensibilización social referidas a este patrimonio, dándolo a conocer entre una ciudadanía que progresivamente lo contempla como rasgo poderoso de identidad cultural.

\section{Plácido González Martínez}

Centro de Documentación del IAPH 